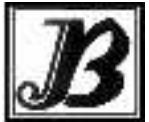

J. bio-sci. 21: 77-87, 2013

ISSN 1023-8654

http://www.banglajol.info/index.php/JBS/index

\title{
INHERITANCE OF LENGTH AND WEIGHT OF MATURE LARVAE IN SIX-PARENT DIALLEL CROSSES OF MULBERRY SILKWORM, BOMBYX MORI L.
}

\author{
H A Rashid ${ }^{1}$, M K Ahsan ", M A Hasan and I Mahfus ${ }^{2}$ \\ Department of Zoology, Rajshahi University, Rajshahi-6205, Bangladesh, \\ ${ }^{1}$ Govt. Rajendra College, Faridpur, Bangladesh, \\ ${ }^{2}$ Monash Institute of Medical research, Monash University, Clayton - 3168, Melbourne, Australia
}

\begin{abstract}
Context: To gain a better understanding of the nature of gene action involved in the inheritance of quantitative characters can be obtained through the use of diallel cross analytical approach for the choice of desirable parents and the formulation of an effective breeding programme.

Objectives: The aim was to study the nature and magnitude of gene action of inheritance for quantitative traits, length and weight of mature larvae in $B$. mori through six-parent diallel cross analysis in four rearing seasons.

Materials and Methods: Six inbred varieties of $B$. mori were used as parents for a diallel cross. The experiment was conducted in four rearing seasons. Mature larval length $(\mathrm{cm})$ and weight $(\mathrm{gm})$ were collected for statistical analysis. The data were analyzed following the biometrical techniques proposed by Jinks and Hayman (1953), Hayman (1954), Dickinson and Jinks (1956) and Jhonson and Aksel (1964).

Results: In the Hayman's analysis of variance for length and weight of mature larvae the items ' $a$ ' and ' $b$ ' were found to be significant against all the three tests of significance. The item ' $\mathrm{b}_{2}$ ' was significant for the seasons $\mathrm{S}$ 2 and S-3 and the ' $b_{3}$ ' item was significant for all the seasons. The Items ' $c$ ' and ' $d$ ' were insignificant in all the seasons. The regressions of $\mathrm{Wr}$ on $\mathrm{Vr}$ for majority of the seasons were significant but did not deviate significantly from unit slope. The varieties Nistari, Nistari oval (G) and NanNung7B of S-1, S-2 and S-4, and Nistari of S-3 for length of larvae and Nistari and Nistari oval (G) of S-1, S-2 and S-3 and Nistari, Nistari oval $(\mathrm{G})$ and Nan Nung 7B of S-4 for larval weight possessed an excess of recessive genes of negative effect. But Nistari oval (G) in S-3 for LL possessed excess of recessive genes with positive effects. On the other hand BSRI-95, BSRI-98 and BV (high) in S-1, S-2 and S-4, and Nan Nung 7B, BSRI-98 and BV(high) in S-3 for LL and BSRI-95, BSRI-98 and BV(high) in S-1, S-2 and S-3, and BSRI-95 and BV(high) in S-4 for LW possessed an excess of dominant genes, which was positive in nature. In S-3 only BSRI-95 for LL and NanNung7B in S-1, S-2 and S-3 and BSRI-98 in S-4 for LW possessed an excess of dominant genes of negative nature. At least one group of dominant genes was involved in controlling these characters. The broad sense heritability was high in all seasons for both the characters whereas the narrow sense heritability was moderate for majority of the seasons except S-3 and S-4 for LW.

Conclusion: High heritability, dominant and recessive gene effects suggest that these parents could be used to develop better lines in respect of larval characters investigated in this study and selection programmes will be effective in early generations.
\end{abstract}

Key words: Inheritance, larval length, larval weight, diallel crosses, Bombyx mori.

\section{Introduction}

The aim of silkworm breeding is to improve economic traits in order to increase the silk productions of sericulture industry. In sericulture numerous traits are considered as important. Growth and yield are two interrelated events for any commercial crop, like for the silkworm rearing. In silkworm energy distribution for silk and egg production is dependent on the growth as well as biomass attained by larvae during postembryonic development. Larval growth is, however, quantitative in nature and knowledge of the mode of inheritance of these characters is a prerequisite to accomplish an effective and meaningful breeding programme in silkworm (Zhao et al. 2007, Hasan et al. 2011).

\footnotetext{
* Corresponding address E-mail:md_kahsan@ru.ac.bd
} 
Diallel cross study has been used to evaluate the potential of parents and crosses in the $F_{1}$ generation, and for analyzing inheritance patterns of genes regulating quantitative characters in silkworms were reported by Krishnaswami et al. (1964), Gamo and Hirabayashi (1983), Jeong et al. (1986), Satenahalli et al. (1989), Sarker et al., (1991), Rahman and Jahan, (2001) and Rahman et al. (2004). However, very meager information is available on the nature of gene actions and their interactions influencing different economic traits of introduced and indigenous varieties of silkworms in Bangladesh. Studies were, therefore, initiated with a $6 \times 6$ complete diallel set of indigenous and introduced varieties of the silkworm, Bombyx mori L. of Bangladesh to characterize the genetic architecture of length and weight of mature larvae, which would facilitate the choice of desirable parents and the formulation of an effective breeding programme.

\section{Materials and Methods}

The materials of the present experiments comprised of six varieties of parents, Bombyx mori L. which include five multivotine: Nistari, Nistari oval (G), BSRI-95, Nan Nung-7B, BSRI-98 and one bivoltine varieties: BV (High) and their $30 \mathrm{~F}_{1} \mathrm{~S}$ obtained by crossing the parents in diallel fashion including reciprocals. The experiment was conducted in four rearing seasons corresponding to commercial rearing seasons as practiced by farmers in Bangladesh. These rearing seasons were Agrahyoni (October-November), Chaita (February-March), Jaistha (May-June) and Bhaduri (August). For each genotype three dfls were brushed in three separate rearing trays $(45 \times 30 \times 6 \mathrm{~cm})$ in a randomized design with three replications. Each rearing tray was considered as a replication in this investigation. Rearing of silkworm larvae was conducted following the scientific technology of Krishnaswami (1978) and Rahman (1983).

Data collected on length $(\mathrm{cm})$ and weight $(\mathrm{g})$ were analyzed following the diallel techniques of analysis as developed by Jinks and Hayman (1953), Hayman (1954), Dickinson and Jinks (1956) and Jhonson and Aksel (1964). Results are interpreted mainly in two approaches. Equations are derived and solved to obtain estimates of the genetic parameters $D, h_{1}, h_{2}, h^{2}$ and $F$ which are interpretable on the basis of diallel theory of Hayman (1954). Alternatively, results in terms of genetical control of the characters are interpreted by constructing graphs.

\section{Results and Discussion}

The present study was conducted during four rearing seasons where considerable variations in the gene interaction were noted because of variations of the environmental conditions. Environmental effects on gene actions had been reported by Allard $(1956 \mathrm{a}, \mathrm{b})$ where he had observed change in dominant effect depending upon the presence or absence of epistasis due to environmental changes. Similar findings were also reported by Sengupta et al. (1974) in B. mori.

The result of Hayman's analysis of variance of diallel table for length and weight of mature larvae is shown in Table 1. The main effects ' $a$ ' and ' $b$ ' were found to be significant against all the three tests of significance viz. $V R_{1}, V_{2}$ and $V R_{3}$ for all the four seasons indicated that both additive and non-additive genetic variations were important in determining the expression of these traits. However, the variation due to additive effect ' $a$ ' had a higher value than any other item in this analysis implying the greater role of additive variation than nonadditive variation. Rahman (1984) reported that both additive and dominance components of genetic variations were important in the inheritance of larval, pupal and cocoon characters in the eri silkworm, Philosamia ricini. 
Table1. Hayman's analysis of variance of diallel table for length and weight of mature larvae in $B$. mori $L$ in different rearing seasons.

\begin{tabular}{|c|c|c|c|c|c|c|c|c|c|}
\hline \multirow{3}{*}{ Item } & \multirow{3}{*}{ d. f. } & \multicolumn{8}{|c|}{ Mean sum of squares } \\
\hline & & \multicolumn{2}{|c|}{ S-1 } & \multicolumn{2}{|c|}{$\mathrm{S}-2$} & \multicolumn{2}{|c|}{ S-3 } & \multicolumn{2}{|c|}{ S-4 } \\
\hline & & $\mathrm{LL}$ & LW & $\mathrm{LL}$ & LW & LL & LW & $\mathrm{LL}$ & $\mathrm{LW}$ \\
\hline a & 5 & $2.29^{* \#+}$ & $2.99^{* \#+}$ & $2.41^{* \#} \dagger^{\dagger}$ & $2.30^{* \#+}$ & $0.89^{* \#+}$ & $0.7^{* *+}$ & $0.61^{*{ }^{* \dagger}}$ & $0.46^{\star \#+}$ \\
\hline$b$ & 15 & $0.33^{\star \# \dagger}$ & $0.46^{* \#+}$ & $0.39^{* \# \dagger}$ & $0.43^{* \#+}$ & $0.50^{\text {*\# }}$ & $0.42^{* \#^{\dagger}}$ & $0.56^{* H^{\dagger}}$ & $0.12^{\star \star \dagger}$ \\
\hline$b_{1}$ & 1 & $0.95^{\star \dagger}$ & $1.11^{\star \dagger}$ & $0.37^{* \# \dagger}$ & $0.12^{\#}$ & $1.41^{\star \dagger}$ & $0.34^{\star \dagger}$ & $2.91^{\star \#^{\dagger}}$ & $0.12^{*}$ \\
\hline$b_{2}$ & 5 & $0.26^{\star \# \dagger}$ & $0.21^{\star \dagger}$ & $0.31^{* \#} \dagger^{\dagger}$ & $0.14^{* *}$ & $0.38^{* \#}$ & $0.16^{\star+}$ & $0.05^{*}$ & $0.02^{\#}$ \\
\hline$b_{3}$ & 9 & $0.30^{* \#}+$ & $0.52^{* H^{\dagger}}$ & $0.44^{* *}{ }^{\dagger}$ & $0.63^{* \#+}$ & $0.47^{\star \star}{ }^{\dagger}$ & $0.57^{* \#^{\dagger}}$ & $0.58^{* \#+}$ & $0.18^{* \dagger}$ \\
\hline c & 5 & 0.006 & $0.022^{+}$ & 0.013 & 0.033 & 0.088 & 0.024 & $0.051^{\text {\#\# }}$ & $0.03^{*}$ \\
\hline$d$ & 10 & 0.019 & 0.004 & 0.016 & 0.013 & 0.027 & 0.007 & $0.065^{\text {*\# }}$ & $0.025^{*}$ \\
\hline $\operatorname{Rep}(\mathrm{R})$ & 2 & 0.002 & 0.013 & 0.007 & 0.039 & 0.011 & 0.0003 & 0.0002 & 0.011 \\
\hline $\mathrm{R} \times \mathrm{a}$ & 10 & 0.033 & 0.058 & 0.028 & 0.044 & 0.051 & 0.008 & 0.018 & 0.016 \\
\hline$R \times b$ & 30 & 0.054 & 0.064 & 0.050 & 0.059 & 0.029 & 0.049 & 0.025 & 0.010 \\
\hline $\mathrm{R} \times \mathrm{b}_{1}$ & 2 & 0.281 & 0.143 & 0.013 & 0.003 & 0.125 & 0.025 & 0.014 & 0.035 \\
\hline $\mathrm{R} \times \mathrm{b}_{2}$ & 10 & 0.012 & 0.096 & 0.091 & 0.035 & 0.018 & 0.071 & 0.034 & 0.0038 \\
\hline $\mathrm{R} \times \mathrm{b}_{3}$ & 18 & 0.051 & 0.038 & 0.032 & 0.079 & 0.024 & 0.039 & 0.021 & 0.011 \\
\hline$R \times C$ & 10 & 0.043 & 0.097 & 0.056 & 0.069 & 0.045 & 0.058 & 0.017 & 0.013 \\
\hline$R \times d$ & 20 & 0.061 & 0.035 & 0.044 & 0.018 & 0.056 & 0.040 & 0.018 & 0.010 \\
\hline $\begin{array}{l}\text { Poole } \\
\text { d error }\end{array}$ & 70 & 0.051 & 0.06 & 0.046 & 0.047 & 0.042 & 0.042 & 0.021 & 0.011 \\
\hline
\end{tabular}

*, \# and ${ }^{\dagger}$ significant at least at $5 \%$ level; tested against pooled error $\left(V_{1}\right)$, interaction with own block $\left(V R_{2}\right)$ and with the item 'd' (VR3) respectively.

The test of significance of item $b_{1}$ in different rearing seasons indicated that at least some directional dominance was present in this diallel which was independent of reciprocal effect. The test of $b_{2}$ item in the Hayman's analysis of variation indicated that the presence of an unequal distribution of dominant alleles among the parents which were independent of reciprocal effect. Finally, ' $b_{3}$ ' portion of ' $b$ ' item for these traits was significant $\left(\mathrm{VR}_{1}, \mathrm{VR}_{2}\right.$ and $\left.\mathrm{VR}_{3}\right)$ in all the seasons. It suggested that there were real deviations of the gene distribution in the parents.

The item ' $c$ ' and ' $d$ ' were insignificant in all the tests of significance $\left(\mathrm{VR}_{1}, \mathrm{VR}_{2}\right.$ and $\left.\mathrm{VR}_{3}\right)$ in S-1, S-2 and S-3 for LL and in S-2 and S-3 for LW implying that there was no reciprocal difference in these diallel for these seasons. Rahman (1994) also reported that there was no reciprocal difference for filament length in the diallel cross of the silkworm, $B$. mori. But reciprocal difference for cocoon size presence in the specific crosses of the silkworm, B. mori was reported by Rahman and Jahan (2001). 
In case of LL Wr-Vr analysis of variance (Table 2) for the seasons S-2 and S-4 indicated that there existed homogeneity among $\mathrm{Wr}-\mathrm{Vr}$ values indicating the probable absence of non-allelic interaction. While for LW, $\mathrm{Wr}-\mathrm{Vr}$ values were significant in all of the seasons which implied the presence of non-allelic interaction in those diallel. The $\mathrm{Wr}+\mathrm{Vr}$ analysis of variance (Table 2) gave significant $\mathrm{Wr}+\mathrm{Vr}$ item for majority of the seasons (except S-3 and S-4 for LW) which suggested presence of a dominant recessive relationship among the parents.

Table 2. Analysis of variance of $(\mathrm{Wr}-\mathrm{Vr})$ and $(\mathrm{Wr}+\mathrm{Vr})$ values of six parent diallel for length and weight of mature larvae in $B$. mori $\mathrm{L}$. in different rearing seasons.

\begin{tabular}{|c|c|c|c|c|c|c|c|c|c|}
\hline \multirow{3}{*}{ Item } & \multirow{3}{*}{ d. f. } & \multicolumn{8}{|c|}{ Mean sum of squares } \\
\hline & & \multicolumn{2}{|c|}{ S-1 } & \multicolumn{2}{|c|}{$\mathrm{S}-2$} & \multicolumn{2}{|r|}{ S-3 } & \multicolumn{2}{|c|}{ S-4 } \\
\hline & & LL & LW & LL & LW & LL & LW & LL & LW \\
\hline Rep. & 2 & 0.0008 & 0.0001 & 0.0033 & 0.001 & $0.0057^{\star \star}$ & 0.0036 & 0.0015 & $0.0012^{\star *}$ \\
\hline $\mathrm{Wr}-\mathrm{Vr}$ & 5 & $0.0037^{\star \star}$ & $0.0089^{* *}$ & 0.0043 & $0.0096^{\star \star}$ & $0.0063^{\star \star}$ & $0.0083^{\star \star}$ & 0.002 & $0.0004^{* *}$ \\
\hline Error & 10 & 0.0005 & 0.0013 & 0.0015 & 0.0012 & 0.0005 & 0.0013 & 0.0017 & 0.0001 \\
\hline Rep. & 2 & 0.0042 & 0.036 & 0.0048 & 0.0261 & $0.0095^{\star}$ & 0.0029 & 0.0028 & 0.0006 \\
\hline$W r+V r$ & 5 & $0.1115^{\star \star}$ & 0.1715 & $0.0768^{\star \star}$ & 0.0393 & $0.017^{\star \star}$ & $0.0233^{\star \star}$ & $0.0233^{\star \star}$ & $0.0047^{\star \star}$ \\
\hline Error & 10 & 0.004 & 0.0532 & 0.0072 & 0.0135 & 0.0019 & 0.0037 & 0.0012 & 0.0003 \\
\hline
\end{tabular}

${ }^{*} \mathrm{P}<0.05$ and ${ }^{* *} \mathrm{P}<0.01, \mathrm{~S}-1$ : Agrahayani (October-November) rearing season, S-2: Chaita (February-March) rearing season, S-3: Jaistha (May-June) rearing season, S-4: Bhaduri (August) rearing season.

The Wr, $\mathrm{Vr}$ graph for larval length and weight are shown in Figs 1 and 2. The regression of Wr on $\mathrm{Vr}$ for majority of the seasons were significant (except S-3 for LL, and S-1 and S-4 for LW) indicating the absence of non-allelic interaction in those diallel. However, the test of significance from zero also supported this view. The regression coefficient did not deviate from unit slope in all the four rearing seasons which is also an indication of the absence of non-allelic interaction in these diallel. The regression line of S-3 and S-4 for LL and S-3 for LW passed below the point of origin of Wr axis indicated the presence of average over dominance. Average partial dominance has been observed in the season S-1 and S-2 for both the traits. Only for LW in S-4 season this line passed through the point of origin indicating complete dominance. The array points 1 (S-1 and S-2), 1 and 2 (S-3), and 1, 2 and 4 (S-4) for LL; 1 and 2 (S-1); 2 (S-2, S-3 and S-4) for $\mathrm{LW}$ are placed furthest from the point of origin indicating the presence of an excess of recessive genes in these arrays. The closest arrays from the point of origin 3, 5 and 6 (S-1), 3 and 5 (S-2) for LL; 6 (S-1 and S4) and 4 (S-3) for LW possessed most of the dominant genes. The arrays 2 and 4 (S-1); 2,4 and 6 (S-2); 3 , 4, 5 and 6 (S-3) and 3, 5 and 6 (S-4) for LL and 3, 4 and 5 (S-1); 1, 3, 4, 5 and 6 (S-2); 3, 5 and 6 (S-3); and 1 and 4 (S-4) for LW possessed more or less equal proportion of dominant and recessive genes as they 
were located in on intermediate position. The array of 1 in S-3 and 6 in S-1 and S-2 for LW found to lie very close to the limiting parabola indicating the presence of heterozygosity in the recurrent parent of those arrays.

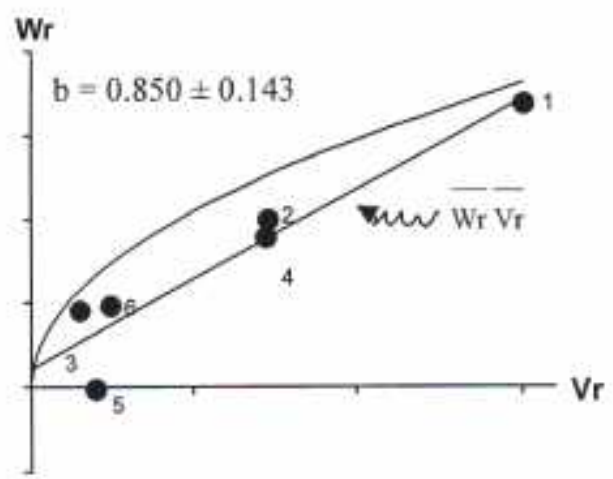

S-1

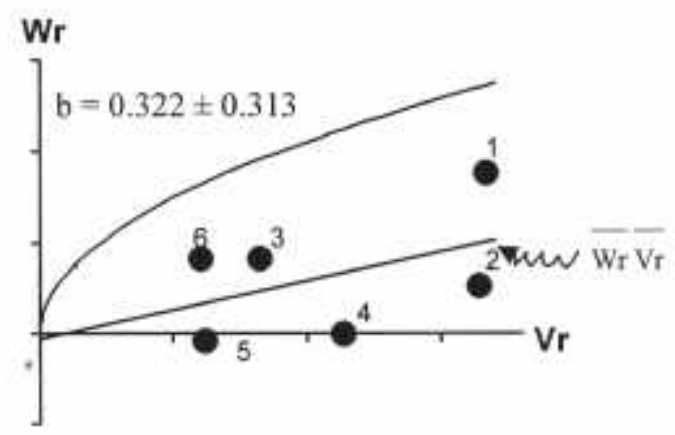

S-3

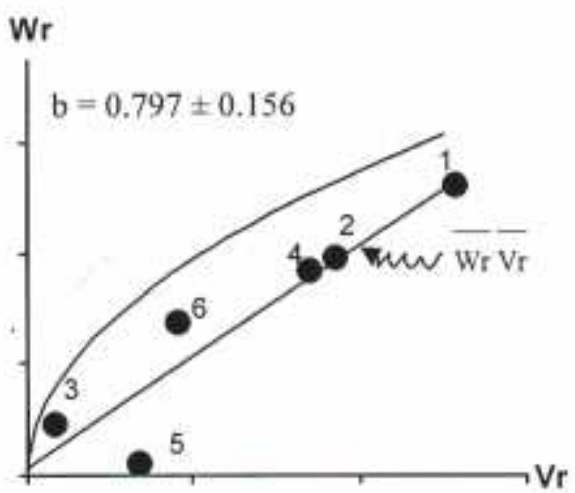

S-2

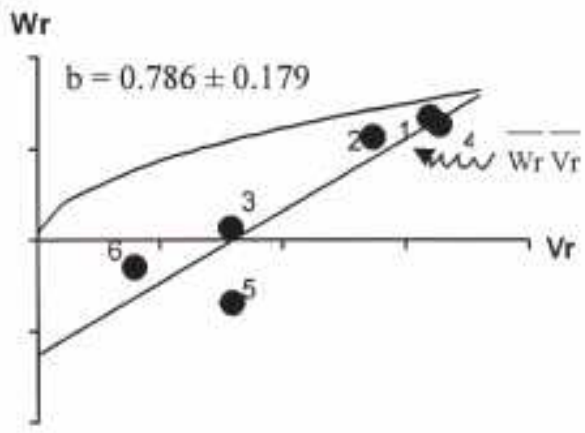

S-4

Fig. 1. The $\mathrm{Wr} / \mathrm{Vr}$ graph for length of mature larvae in different rearing seasons. 


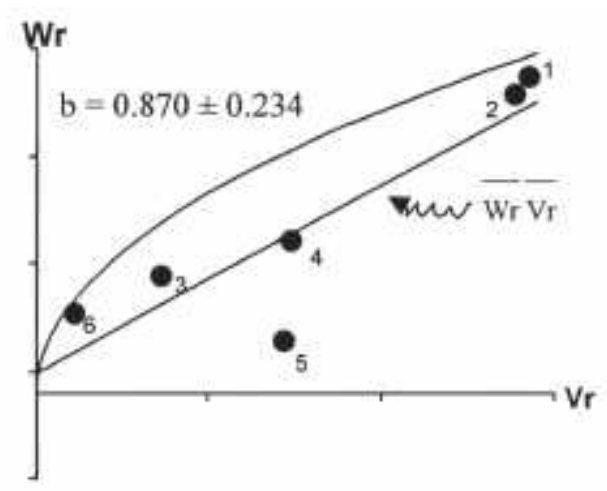

S-1

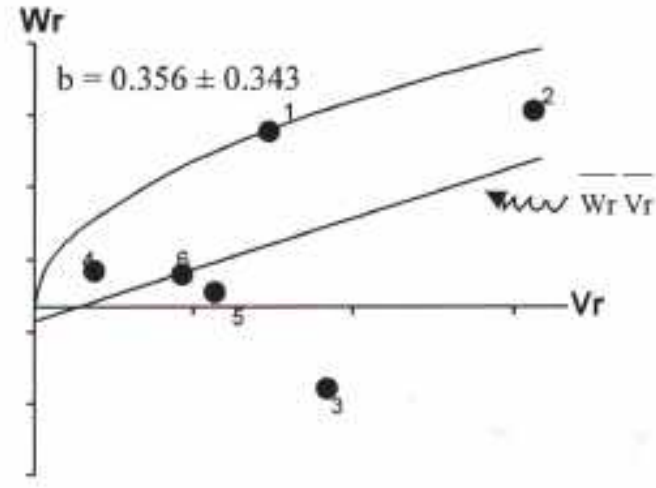

S-3

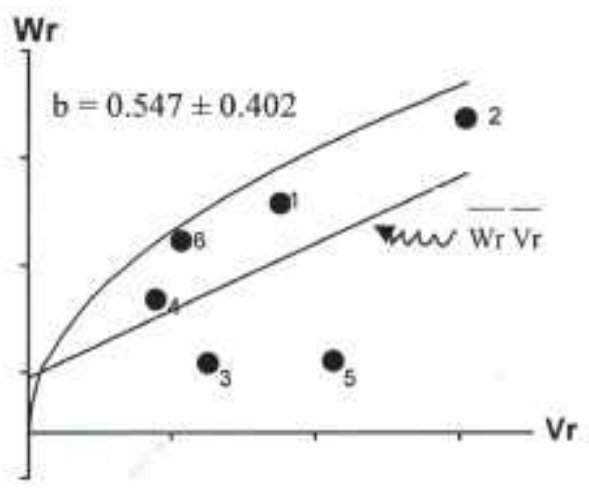

S-2

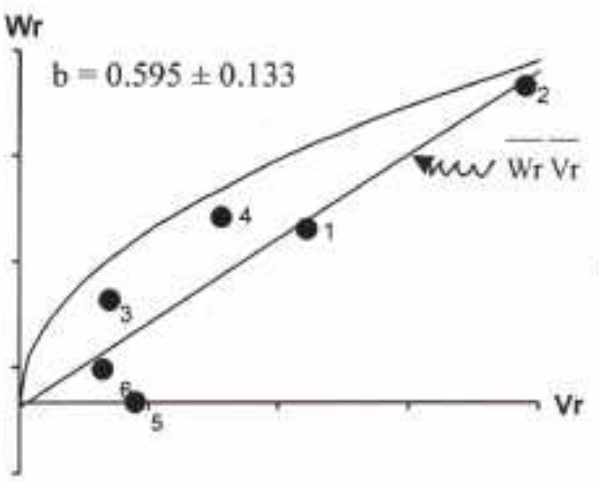

S-4

Fig. 2. The $\mathrm{Wr} / \mathrm{Vr}$ graph for weight of mature larvae in different rearing seasons.

The standardized deviation graph of $\hat{\mathrm{Yr}}$ and $\hat{\mathrm{Wr}}+\hat{\mathrm{V} r}$ was drawn for length and weight of mature larvae to determine the direction of dominance (Fig. 3 and 4). These showed that the arrays 1, 2 and 4 of S-1, S-2 and S-4, and 1 of S-3 for LL and the arrays 1 and 2 of S-1, S-2 and S-3 and 1, 2 and 4 of S-4 for LW possessed an excess of recessive genes of negative effect. But the array 2 in S-3 for LL possessed excess of recessive genes with positive effects. On the other hand 3, 5 and 6 in S-1, S-2 and S-4, and 4, 5 and 6 in S-3 for LL and 3, 5 and 6 in S-1, S-2 and S-3, and 3 and 6 in S-4 for LW possessed an excess of dominant genes, which was positive in nature. In S-3 only the array 3 for LL and array 4 in S-1, S-2 and S-3 and 5 in S-4 for LW possessed an excess of dominant genes of negative in nature. 


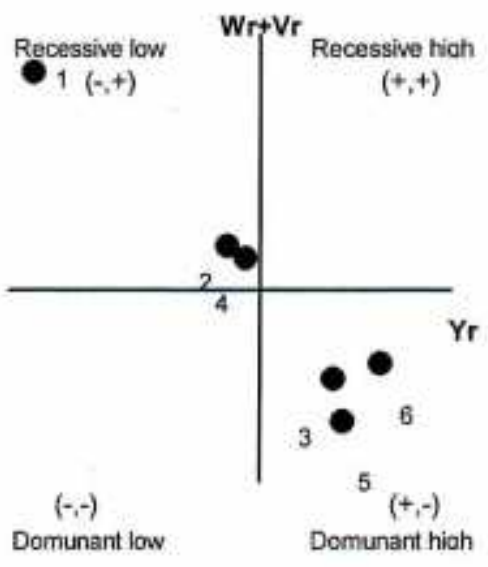

S-1

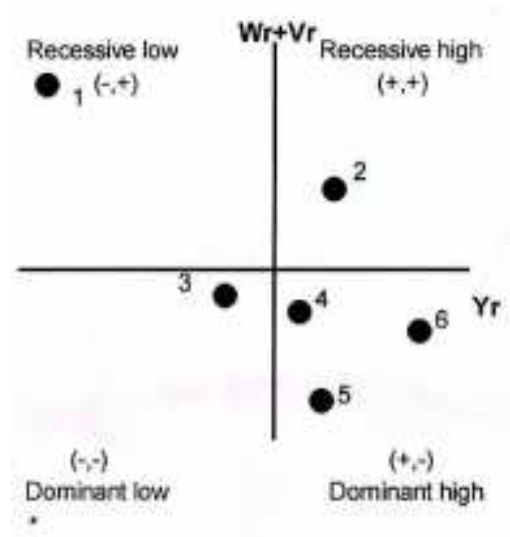

S-3

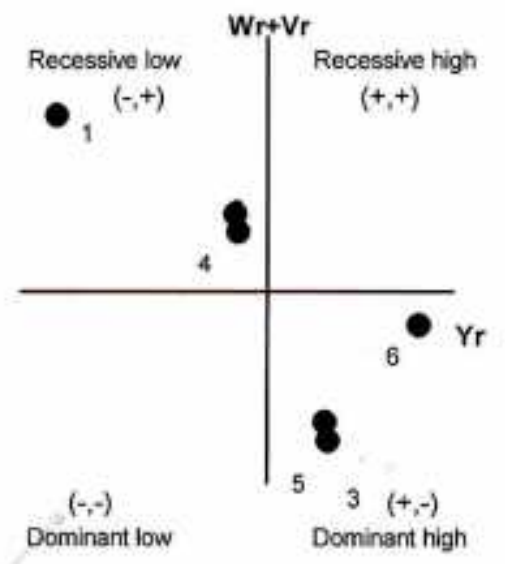

S-2

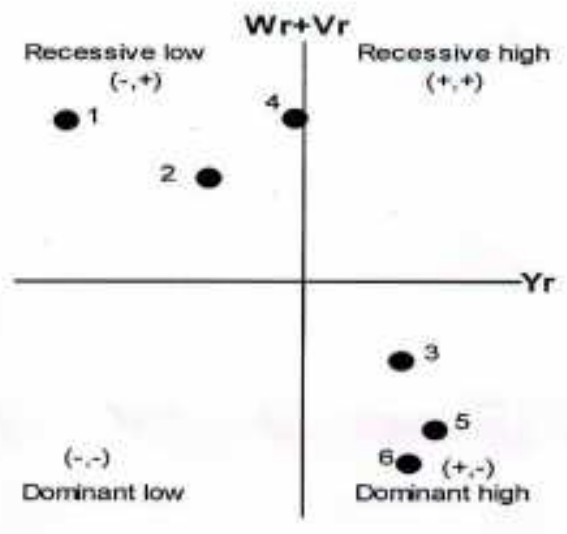

S-4

Fig. 3. The standardized deviation graph for length of mature larvae in different rearing seasons. 


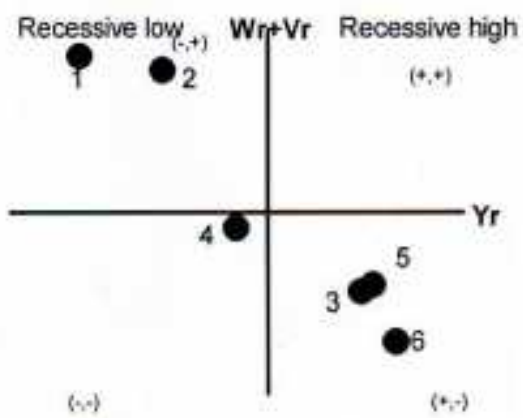

Dominant low
S-1

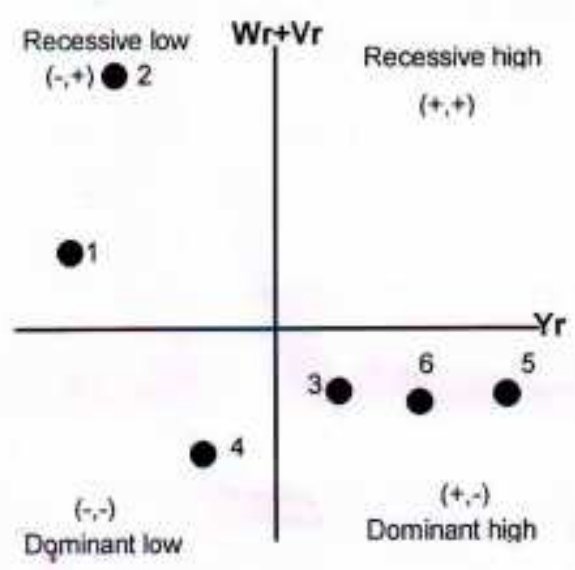

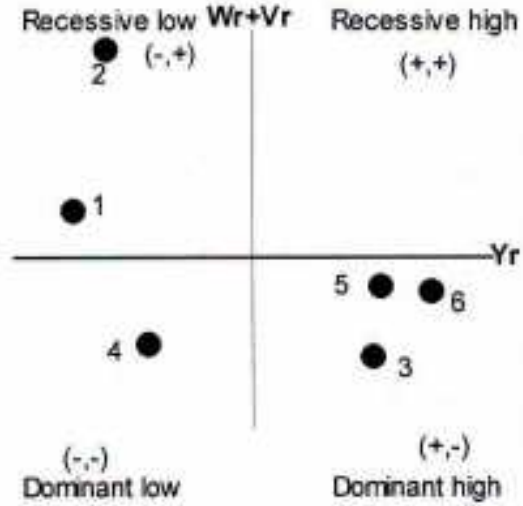

S-2

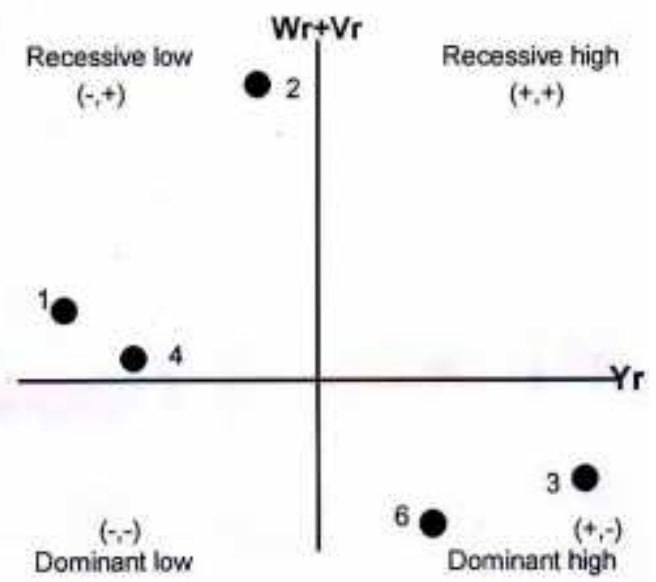

S-3

S-4

Fig. 4. The standardized deviation graph for weight of mature larvae in different rearing seasons.

Estimates of component of variations and their ratios for $L L$ and $L W$ have been shown in Table 3. The significant values of $(\hat{D})$ and $\left.\hat{(H}_{1}\right)$ for all the seasons except in S-3 for $(\hat{D})$ of LW indicated the important role of both additive and non-additive genetic variations in the inheritance of length and weight of mature larvae. 
Table 3. Components of variation and their ratios obtained from six parent diallel analysis for length and weight of mature larvae in $B$. mori $L$. in different rearing seasons.

\begin{tabular}{|c|c|c|c|c|c|c|c|c|}
\hline \multirow{3}{*}{$\begin{array}{l}\text { Components \& } \\
\text { Ratios }\end{array}$} & \multicolumn{8}{|c|}{ Estimated values with standard error in different seasons } \\
\hline & \multicolumn{2}{|c|}{ S-1 } & \multicolumn{2}{|c|}{ S-2 } & \multicolumn{2}{|c|}{$S-3$} & \multicolumn{2}{|c|}{ S-4 } \\
\hline & LL & LW & LL & LW & LL & LW & LL & LW \\
\hline $\mathrm{E}$ & $\begin{array}{l}0.017 \\
\pm 0.01\end{array}$ & $\begin{array}{c}0.019 \\
\pm 0.015\end{array}$ & $\begin{array}{l}0.015 \\
\pm 0.01\end{array}$ & $\begin{array}{c}0.015 \\
\pm 0.017\end{array}$ & $\begin{array}{c}0.014 \\
\pm 0.013\end{array}$ & $\begin{array}{c}0.014 \\
\pm 0.015\end{array}$ & $\begin{array}{c}0.007 \\
\pm 0.006\end{array}$ & $\begin{array}{c}0.004 \\
\pm 0.004\end{array}$ \\
\hline D & $\begin{array}{c}0.263 \\
\pm 0.025\end{array}$ & $\begin{array}{c}0.324 \\
\pm 0.039\end{array}$ & $\begin{array}{c}0.227 \\
\pm 0.025\end{array}$ & $\begin{array}{c}0.199 \\
\pm 0.045\end{array}$ & $\begin{array}{c}0.096 \\
\pm 0.034\end{array}$ & $\begin{array}{c}0.048 \\
\pm 0.041\end{array}$ & $\begin{array}{c}0.031 \\
\pm 0.016\end{array}$ & $\begin{array}{c}0.026 \\
\pm 0.009\end{array}$ \\
\hline $\mathrm{F}$ & $\begin{array}{c}0.061 \\
\pm 0.061\end{array}$ & $\begin{array}{c}0.033 \\
\pm 0.096\end{array}$ & $\begin{array}{c}0.023 \\
\pm 0.061\end{array}$ & $\begin{array}{l}-0.031 \\
\pm 0.110\end{array}$ & $\begin{array}{c}0.077 \\
\pm 0.082\end{array}$ & $\begin{array}{c}0.001 \\
\pm 0.099\end{array}$ & $\begin{array}{l}-0.028 \\
\pm 0.039\end{array}$ & $\begin{array}{l}-0.023 \\
\pm 0.023\end{array}$ \\
\hline $\mathrm{H}_{1}$ & $\begin{array}{c}0.234 \\
\pm 0.064\end{array}$ & $\begin{array}{c}0.299 \\
\pm 0.099\end{array}$ & $\begin{array}{c}0.291 \\
\pm 0.064\end{array}$ & $\begin{array}{c}0.276 \\
\pm 0.115\end{array}$ & $\begin{array}{c}0.382 \\
\pm 0.086\end{array}$ & $\begin{array}{c}0.279 \\
\pm 0.103\end{array}$ & $\begin{array}{c}0.366 \\
\pm 0.041\end{array}$ & $\begin{array}{c}0.076 \\
\pm 0.024\end{array}$ \\
\hline $\mathrm{H}_{2}$ & $\begin{array}{c}0.187 \\
\pm 0.057\end{array}$ & $\begin{array}{c}0.265 \\
\pm 0.089\end{array}$ & $\begin{array}{c}0.231 \\
\pm 0.057\end{array}$ & $\begin{array}{c}0.255 \\
\pm 0.103\end{array}$ & $\begin{array}{c}0.308 \\
\pm 0.077\end{array}$ & $\begin{array}{c}0.252 \\
\pm 0.093\end{array}$ & $\begin{array}{c}0.359 \\
\pm 0.037\end{array}$ & $\begin{array}{c}0.074 \\
\pm 0.021\end{array}$ \\
\hline$\hat{\mathrm{h}}^{2}$ & $\begin{array}{c}0.167 \\
\pm 0.038\end{array}$ & $\begin{array}{c}0.195 \\
\pm 0.059\end{array}$ & $\begin{array}{c}0.059 \\
\pm 0.038\end{array}$ & $\begin{array}{c}0.012 \\
\pm 0.069\end{array}$ & $\begin{array}{c}0.254 \\
\pm 0.051\end{array}$ & $\begin{array}{c}0.055 \\
\pm 0.062\end{array}$ & $\begin{array}{c}0.535 \\
\pm 0.025\end{array}$ & $\begin{array}{c}0.019 \\
\pm 0.014\end{array}$ \\
\hline$\hat{\mathrm{h}}^{2} / \mathrm{H}_{2}$ & 0.896 & 0.735 & 0.257 & 0.046 & 0.825 & 0.217 & 1.491 & 0.259 \\
\hline$\sqrt{\hat{\mathrm{H}}_{1}} / \hat{\mathrm{D}}$ & 0.943 & 0.960 & 1.131 & 1.176 & 1.990 & 2.419 & 3.451 & 1.719 \\
\hline $1 / 4\left(\hat{D}-\hat{H}_{1}\right)$ & 0.007 & 0.006 & -0.016 & -0.019 & -0.071 & -0.058 & -0.084 & -0.013 \\
\hline$\hat{\mathrm{H}}_{2} / 4 \hat{\mathrm{H}}_{1}$ & 0.199 & 0.221 & 0.199 & 0.231 & 0.201 & 0.226 & 0.245 & 0.244 \\
\hline$\stackrel{1 / 2}{\hat{F}} / \sqrt{\hat{D}\left(\hat{\mathrm{H}}_{1}-\hat{\mathrm{H}}_{2}\right)}$ & 0.270 & 0.156 & 0.101 & -0.236 & 0.453 & 0.018 & -0.956 & -1.723 \\
\hline $\begin{array}{l}\text { Heritability } \\
\text { (Narrow sense) }\end{array}$ & 0.7457 & 0.6957 & 0.6801 & 0.5455 & 0.5775 & 0.3303 & 0.4815 & 0.9623 \\
\hline $\begin{array}{c}\text { Heritability } \\
\text { (Broad sense) }\end{array}$ & 0.9331 & 0.9308 & 0.9341 & 0.9114 & 0.9363 & 0.8815 & 0.9336 & 0.8473 \\
\hline
\end{tabular}

The values of $\hat{\mathrm{F}}$ were positive in all the seasons for $L L$ and in S-1, S-3 for $L W$ indicating the presence of an excess of dominant genes in the parents while for $L W$ the insignificant negative $\hat{\mathrm{F}}$ estimates revealed that an excess of recessive genes is present in the seasons S-2 and S-4. The significant $\left(\hat{H}_{2}\right)$ of all four seasons indicated the dominance asymmetry of positive and negative effects of genes in the parents for these traits. Similar results were obtained by the negative value of the ratio $1 / 4\left(\hat{D}-\hat{H}_{1}\right)$ in the three seasons $S-2, S-3$ and 
S-4 while S-1 showed the positive value. The average degree of dominance $\left(\hat{H}_{1} / \hat{D}\right)^{1 / 2}$ was more than unity for S-2 (1.176), S-3 (2.419) and S-4 (1.720) suggesting the presence of a higher proportion of over dominance.

The distribution of dominant and recessive alleles estimated by the ratio $\hat{\mathrm{H}}_{2} / 4 \hat{\mathrm{H}}_{1}$ was close to 0.25 in S-3 (0.245) for LL and all seasons for LW suggesting that there was symmetry in the allelic distribution. The number of effective factors determined from the ratio $\hat{\mathrm{h}}^{2} / \hat{\mathrm{H}}_{2}$ indicated that at least one group of dominant genes was involved in controlling these traits. The ratio $h / d$ as mentioned by the quantity $1 / 2 \hat{F} / \sqrt{\hat{D}\left(\hat{H}_{1}-\hat{H}_{2}\right)}$ were less than one for majority of the seasons except S-4 for LW indicating the presence of more recessive alleles than dominant alleles in the inbred lines. The narrow sense heritability for LL and LW in S-1, S-2, S-3 and S-4 respectively were found to be $74.56,68.01,57.74,48.15 \%$ and $69.57,54.55,33.02,9.62 \%$ and broad sense heritability were $93.31,93.40,93.62,93.36 \%$ and $93.07,91.14,88.14,84.73 \%$ (Table 3).

Examination of results reveal that both additive and dominance components of genetic variation are important in the inheritance of these traits. Both types of analysis, i.e., Hayman's analysis of variance and component of variation gave the similar information. Highly significant values for additive ( $\mathrm{a}$ and $\hat{\mathrm{D}}$ ) and nonadditive ( $b$ and $\hat{H}_{1}$ ) components of variation depicted wide genetic variability among the parents included for the present investigation. The present analysis was substantiated by the findings of Gamo et al. (1985), Hirabayashi and Gamo (1985), Jeong et al. (1986), Rahman and Jahan, (2001) and Rahman et al. (2004) in the mulberry silkworm. On the other hand, the regression lines in $\mathrm{Wr}, \mathrm{Vr}$ graph, indicated a similar result in some of the seasons but differed in others. Jinks (1955) and Allard (1956b) in their analysis of diallel crosses have shown that over dominance indicated by the ratio $\left(\hat{\mathrm{H}}_{1} / \hat{\mathrm{D}}\right)^{1 / 2}$ might be confounded with the non-allelic interactions. As to the practical implication of these results, it is suggested that the development of high yielding breeds in respect to larval growth may be achieved through simultaneous utilization of both additive and dominance variation by selection processes in further generations.

\section{References}

Allard RW. 1956 a. The analysis of genetic environmental interactions by means of diallel crosses. Genetics 41. 305-319.

Allard RW. 1956 b. Estimation of potency from lima bean diallel crosses. Agron. J. 48: 537-543. http://dx.doi.org/10.2134/agronj1956.00021962004800120002x

Dickinson AG, Jinks JL. 1956. A general analysis of diallel crosses. Genetics 41: 65-78.

Gamo T, Hirabayashi T. 1983. Genetic analysis of growth rate population rate and some quantitative characters by diallel cross in the silkworm, Bombyx mori L. Jap. J. Breed. 33: 178-90. http://dx.doi.org/10.1270/jsbbs1951.33.178

Gamo T., Otsuka, Y., Fujishima, T., Hirobe, T. \& Tazima, Y. 1985. Estimation of combining ability and genetic analysis by diallel crosses between regional races of silkworm (1) Rearing performances and cocoon yields. Tech. Bull. Seri. Expt. Sta. 126: 93-120.

Hasan, M.A., Rahman, S.M. \& Ahsan, M.K. 2011. Genetic variability, correlation, path analysis and construction of selection index in mulberry silkworm, Bombyx mori L. I. Genetic variability. Univ. j. zool. Rajshahi Univ. 30: 33-36.

Hayman, B.I. 1954. The analysis of variance of diallel crosses. Genetics 39: 789-809. 
Hirabayashi, T. \& Gamo, T. 1985. Study on the combining ability of Japanese and Chinese silkworm races with different voltinism by dialleld cross III. Shape and size of cocoons and their genetic analysis. Tech. Bull. Seri. Expt. Sta. 125: 91-104.

Jeong, W.B., Chang, K.Y., Han, K.S., Kim, J.H., Ryu, K.D., Dhung, H.Y. \& Ryu, S.C. 1986. Genetic analysis by diallel crosses in $\mathrm{F}_{1}$ generation of silkworm, B. mori L. Korean J. Seric. Sci. 28(1): 24-29.

Jinks, J.L. 1955. A survey of the genetical basis of heterosis in a variety of diallel crosses. Heredity 9: 223-228. http://dx.doi.org/10.1038/hdy.1955.21

Jinks, J.L. 1956. The $F_{2}$ and backcross generation from a set of diallel crosses. Heredity 10: 1-30. http://dx.doi.org/10.1038/hdy.1956.1

Jinks, J.L. \& Hayman, B.I. 1953. The analysis of diallel crosses. Maize Genetics . News Letter 27: 48-54.

Johnson, L.P.V. \& Aksel, R. 1964. The inheritance of malting quality and agronomic characters in a diallel cross of barley. Can. J. Genet. Cytol. 6: 178-200. http://dx.doi.org/10.1139/g64-024

Krishnaswami S. 1978. New technology of silkworm rearing. Central Silk Board, Bombay, India. 23 pp.

Krishnaswami, S., Jolly, M.S. \& Subbarao, G. 1964. Diallel analysis of quantitative characters in multivoltine races of silkworm. Indian J. Genet. 24(3): 213-222.

Rahman M.A. 1983. Technology of mulberry silkworm rearing suitable for the climatic condition in Bangladesh. Reshom 1: $71-79$.

Rahman, M.S. 1984. Studies on the genetic improvement of eri silkworm, Philosamia ricini. Boisd. of Bangladesh. Ph. D. thesis. Department of Zoology, Rajshahi University. 419pp.

Rahman, S.M. 1994. Filament length inheritance in a six-parent diallel cross in the silkworm, Bombyx mori L. Bangladesh J. Zool. 22(2): 209-215.

Rahman, S.M. \& Jahan, S. 2001. Gene action on cocoon size in silkworm, Bombyx mori L. (Lepidoptera: Bombycidae). Univ. J. Zool. Rajshahi Univ. 20: 67-70.

Rahman, S.M., Ali, I.A. \& Rashid, H.A. 2004. Inheritance of fecundity and fertility in silkworm, Bombyx mori L. from all possible crosses between a set of parental lines. Univ. J. Rajshahi Univ. 23: 69-72.

Sarker, A., Das, N.K. \& Das, B.C. 1991. A diallel cross analysis of the cocoon weight in the silkworm, Bombyx mori L. Sericologia 31(2): 301-306.

Satenahalli SB, Govindan R, Goud JV. 1989. Genetic analysis of some quantitative traits by diallel cross in silkworm, Bombyx mori L. Sericologia 29(3), 333-342.

Sengupta K, Datta RK, Biswas SN. 1974. Effect of multiple crossing on the population pattern of the progeny in silkworm. Indian J. genet. 34A (Sabrao Proc), 241-248.

Zhao Y, Chen K, He S. 2007. Key principles for breeding spring-and-autumn using silkworm varieties: from our experience of breeding 873×874. Caspian J Env Sci 5(1), 57-61. 